\title{
Sensory and color properties of dietary cookies with different fiber sources during 180 days of storage
}

\author{
Jovanka V. Popov-Raljić ${ }^{1}$, Jasna S. Mastilović ${ }^{2}$, Jovanka G. Laličić-Petronijević ${ }^{1}$, Žarko S. Kevrešan ${ }^{2}$, \\ Mirjana A. Demin ${ }^{1}$ \\ ${ }^{1}$ University of Belgrade, Faculty of Agriculture, Belgrade, Serbia \\ ${ }^{2}$ University of Novi Sad, Institute for Food Technology, Novi Sad, Serbia
}

\begin{abstract}
The aim of this study was to examine the sensory properties of dietary cookies produced with addition of different dietary fiber sources (inulin and oligofructose, oat flakes, mixture of oat flakes and wholemeal flour, wholemeal flour and mixture of wholemeal flour and carob flour), and to measure instrumentally color changes of cookies upper and lower surfaces, after storage at temperatures of $18-20{ }^{\circ} \mathrm{C}$ for 180 days. Addition of inulin and oligofructose was determined to be the fiber source with the highest impact on sensory properties. Storage for 180 days expressed the highest influence on texture properties of dietary cookies regardless of applied dietary fiber source. Color differences calculated from measured color properties (psychometric light, $L^{*}$, psychometric tone, $a^{*}$, and psychometric chrome, $b^{*}$ ) between products including different fiber sources were noticeable to extremely noticeable among products, with the most expressed difference was registered for products containing carob flour.
\end{abstract}

Keywords: dietary cookies, sensory attributes, color measurement, composition, storage.

SCIENTIFIC PAPER

UDC 664.68:615.874.2:66

Hem. Ind. 67 (1) 123-134 (2013)

doi: 10.2298/HEMIND120327047P

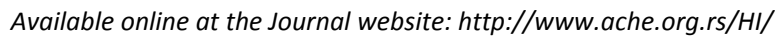

Cookies belong to the group of food products that are very popular in daily diet of almost all profiles of consumers [1], having not only the nutritive purpose but influencing also on emotional status of consumers with the effects even on the positive mood enhancement [2]. Cookies are characterized with quite long shelf life, which results in their availability almost everywhere at any time $[3,4]$. Therefore, the alteration of composition of cookies directed to enhancement their nutritive and/or functional properties or to enabling of their consumption to the groups of consumers with special needs and demands has been the subject of interest of many researchers. The basic composition of cookies enables a variety of different possibilities for achievement of dietary properties of the products with respect to type, share and function of three main components for cookie dough production: flour [5-7], fat and sugar $[7,8]$. There are different possibilities for development and production of dietary cookies, from sugar replacement [9-14] or reduction [15], over alteration of fat shares, composition and properties [16-21] to enrichment of cookies with different functional components [22-24].

The deficit of fiber intake in the diet of the average consumer positioned the issue of development and production of dietary fiber enriched cookies as the

Correspondence: J.S. Mastilović, University of Novi Sad, Institute for Food Technology, Novi Sad, Bulevar cara Lazara 1, Serbia.

E-mail: jasna.mastilovic@fins.uns.ac.rs

Paper received: 27 March, 2012

Paper accepted: 7 May, 2012 point of interest for both producers and researchers. For production of dietary cookies enriched with dietary fibers, components such as cellulose, hemicelluloses, lignin, inulin [25], gum, modified cellulose, mucus, oligosaccharides, pectin and waxes [26] can be used. Different sources of fiber as the bioactive carbohydrates [27-28] like rice bran [29-31], inulin and oligofructose [32] pulse flours [33] were tested and proven as possible fiber sources in cookies.

Influence of fiber addition on dough behavior and its relation to structural [34], and nutritive properties $[35,36]$, starch degradation and texture [37] were thoroughly investigated.

Dietary fibers present in the dough for dietary biscuits have an impact on their rheological properties, water activity, viscosity test and sensory characteristics. Thus, cellulose and pectin enhance viscosity. Inulin and $\beta$-glucan in the dough for dietary cookies have an impact on the reduction of viscous properties, rising of dough during baking, as well as resistance of the dough [37].

Potential fiber sources in cookies like oats [38] and carob [39], beside the basic dietetic gastrointestinal effect [40], were also confirmed to be a source of antioxidant activity.

According to the findings of Bilgiçli et al. [36] utilization of $0-30 \%$ replacements of wheat flour with fibers from apple, lemon and wheat does not significantly affect the change in nutritional status of samples of cookies, while the supplement of wheat bran significantly reduces their nutritional properties. 
Unlike other cereals, oat is an excellent source of dietary fiber, such as 1.3 and $1.4 \beta$-glucan, arabinoxylans and cellulose, and in large quantities contain proteins, lipids, vitamins, antioxidants, phenolic compounds and minerals. It has beneficial effects on reducing blood cholesterol and reduces the risk of heart disease [40]. Extruded oat flakes are widely used in food industry, as a breakfast cereals and as snack products [38,41,42]. Sreenath et al. [27] examined characteristics of certain dietary fibers from the seed hull of field beans and waste pulp of pineapple as well as from whole wheat flour, in the preparation of dietary cookies. The authors conclude that sensory properties do not significantly change with dietary fiber addition. Carob has wide application in the confectionery industry where it is used as a substitute for chocolate, as a tanning agent or stabilizer, proven to be the source of both fibers and antioxidants [28,39].

Potential fiber sources for production of fiber enriched dietetic cookies are very diverse in particle size, content of other constituents, consistency and color. For this reason one of the main challenges of development of fiber enriched dietetic cookies might be the preservation of sensory properties, especially of color at acceptable level. Replacement of a part of flour as the basic cookie constituent with fiber rich raw materials will also reflect at the interactions of cookie constituents during the storage influencing thus the changes of sensory properties during the storage time.

The aim of this study was to compare the influence of addition of most frequently used fiber sources on sensory properties and instrumentally measured color of cookies including determination of examined properties after production and their changes after the usual shelf life before the consumption, which can be up to 180 days.

\section{EXPERIMENTAL PROCEDURE}

\section{Material}

Dietary cookies with fiber supplemented from different soluble and insoluble fiber sources were produced under laboratory conditions. All ingredients were mixed in spiral mixer SP 12-SP 160. Dough was left to rest at room temperature for one hour, and then it was ma- nually sheeted to $5 \mathrm{~mm}$ thickness and cut by pressing molds onto dough sheet. Baking was performed in a rotating oven (Terming, Belgrade) at $200{ }^{\circ} \mathrm{C}$ for $20 \mathrm{~min}$. After cooling for $30 \mathrm{~min}$ to room temperature, produced cookies were wrapped in the packaging material, and stored in dark at the temperature of $18-20^{\circ} \mathrm{C}$.

The basic composition of dietary cookies consisted of flour and fiber source mixture representing together polymeric carbohydrate component (100\%), to which vegetable fat (20\%), sugar (20\%) and growing agents (E500ii, E-503ii) (1\%) were added in order to obtain dough for cookie production. The composition of mixture of flour and fiber sources was alternated to obtain dietary cookies with different fiber sources (Table 1).

\section{Methods}

Analysis of cookie samples was performed after production and cooling of the samples and after storage of 180 days. Sample analysis included:

1. Assessment of sensory properties of dietary cookies by the panel of trained and experienced assessors;

2. Measurement of color properties in CIEL*a*b* color system using "Minolta" Chroma meter CR 400 color measurement equipment.

\section{Sensory analysis}

Analysis of sensory properties was conducted according to the options of relevant ISO standards [43$-50]$. For selection, training and monitoring of assessors the ranking method was applied. Sensory analysis was conducted for fresh cooled products and after 180 days production.

The assessment procedures of scoring was based on assessment of representative quality attributes chosen by Popov-Raljić et al. [51] as the best fitting attributes for scoring of confectionary products such as cookies, crackers and salty pastry. A score list with 5 points (1 to 5) was applied. Each quality level expressed with the corresponding score (point) was precisely defined (Table 2) with differences between scores defined so that the assessors could easily distinguish them.

\section{Color measurements}

Colors of fresh cooled cookies and cookies stored for 180 days were measured instrumentally using a

Table 1. Compositions of mixtures of flour and dietary fiber sources used for dietary cookies production

\begin{tabular}{|c|c|c|c|c|c|c|}
\hline \multirow{2}{*}{ Sample } & \multirow{2}{*}{ Fiber source description } & \multicolumn{5}{|c|}{ Polymeric carbohydrate component constituents, $\%$} \\
\hline & & Wholemeal wheat flour & Oat flakes & Carob flour & Inulin & Oligo-fructose \\
\hline 1 & Inulin + oligofructose & - & - & - & 6 & 6 \\
\hline 2 & Oat flakes & - & 30 & - & - & - \\
\hline 3 & Oat flakes + wholemeal flour & 30 & 20 & - & - & - \\
\hline 4 & Wholemeal flour & 30 & - & - & - & - \\
\hline 5 & Wholemeal flour+carob & 30 & - & 9 & - & - \\
\hline
\end{tabular}


Table 2. Quality attributes scored in sensory assessment of dietary cookies

\begin{tabular}{|c|c|c|c|}
\hline Quality attribute & Definition & Scores & Description \\
\hline \multirow[t]{5}{*}{ Appearance } & \multirow{5}{*}{$\begin{array}{c}\text { Visually assessed } \\
\text { appearance of } \\
\text { surface and shape } \\
\text { of cookies }\end{array}$} & 5 & Even surface, no breakages, regular shape, without damages \\
\hline & & 4 & Hardly visible breakages, slight shape irregularities, without damage \\
\hline & & 3 & Visible breakages, shape irregularities, without damages \\
\hline & & 2 & Breakages dominating over surface, irregular shape, slight damages \\
\hline & & 1 & Intense breakage at the surface, deformed shape, serious damages \\
\hline \multirow[t]{5}{*}{ Texture } & \multirow{5}{*}{$\begin{array}{c}\text { Visually and } \\
\text { palpatory assessed } \\
\text { structure of } \\
\text { breakage }\end{array}$} & 5 & Even porosity, uniform breakage, no crumbling \\
\hline & & 4 & Inherent porosity with slight breakage deviations and crumbling \\
\hline & & 3 & Layered structure with unevenly distributed cavities and notable crumbling \\
\hline & & 2 & Uneven porosity and breakage with significant crumbling \\
\hline & & 1 & Totally untypical porosity and breakage, intensive crumbling \\
\hline \multirow[t]{5}{*}{ Mouth sensation } & \multirow{5}{*}{$\begin{array}{c}\text { Orally assessed } \\
\text { chewiness and } \\
\text { crispness }\end{array}$} & 5 & Very crispy by biting, very easy melting in the mouth \\
\hline & & 4 & Crispy by biting, easy melting in the mouth \\
\hline & & 3 & Slightly crispy by biting, still melting in the mouth \\
\hline & & 2 & Not very crispy by biting, not easy melting in the mouth \\
\hline & & 1 & Absence of crispiness, difficult melting in the mouth \\
\hline \multirow[t]{5}{*}{ Aroma } & \multirow{5}{*}{$\begin{array}{c}\text { Olfactory assessed } \\
\text { aroma }\end{array}$} & 5 & Very pleasant aroma characteristic for cookies \\
\hline & & 4 & Pleasant aroma characteristic for cookies \\
\hline & & 3 & Aroma characteristic for cookies \\
\hline & & 2 & Aroma slightly uncharacteristic for cookies \\
\hline & & 1 & Aroma uncharacteristic for cookies \\
\hline \multirow[t]{5}{*}{ Taste } & Orally assessed & 5 & Very pleasant taste characteristic for cookies \\
\hline & taste & 4 & Pleasant taste characteristic for cookies \\
\hline & & 3 & Taste characteristic for cookies \\
\hline & & 2 & Taste slightly uncharacteristic for cookies \\
\hline & & 1 & Taste uncharacteristic for cookies \\
\hline
\end{tabular}

tristimulus photoelectric colorimeter "Minolta" Chroma meter CR 400, with light source D, standard viewer 65을 and light beam diameter $8 \mathrm{~mm}$. Color was measured at three predetermined places of the dietary cookies top and bottom surfaces. Results were expressed in CIE $\mathrm{L}^{*} \mathrm{a}{ }^{*} \mathrm{~b}$ color model which is based on the color perception of $92 \%$ of the population that does not have vision deficiencies $[52,53]$. The results were given as the mean values of psychometer light, $L^{*}$, psychometer tone, $a^{*}$ and psychometer chroma, $b^{*}$, calculated from the following equations [54]:

$$
\begin{aligned}
& L^{*}=116\left(\frac{Y}{Y_{0}}\right)^{\frac{1}{3}}-16 \\
& a^{*}=500\left[\left(\frac{X}{X_{0}}\right)^{\frac{1}{3}}-\left(\frac{Y}{Y_{0}}\right)^{\frac{1}{3}}\right] \\
& b^{*}=200\left[\left(\frac{Y}{Y_{0}}\right)^{\frac{1}{3}}-\left(\frac{Z}{Z_{0}}\right)^{\frac{1}{3}}\right]
\end{aligned}
$$

where $a^{*}$ is the psychometric tone: participation of red $(+)$ and green $(-)$ colors of components; $b^{*}-$ psychometric chroma: participation of yellow $(+)$ and blue $(-)$ colors of components.

Based on the obtained values of $L^{*}, a^{*}$ and $b^{*}$, additional parameters defining the properties of color of dietary cookies were calculated. The hue angle, $h^{\circ}$, was computed by converting the CIEL*a*b* coordinates from rectangular form to polar form and it represents the position of the color in the spectrum. Chroma, $C^{*}$, is the aspect of color in by which a sample appears to differ from a gray of the same lightness or brightness. The color saturation, $s$, is determined by a combination of light intensity and how much it is distributed across the spectrum of different wavelengths. For calculation of mentioned parameters the following equations were applied:

$$
\begin{aligned}
& h^{\circ}=\tan ^{-1} \frac{b^{*}}{a^{*}} \\
& C^{*}=\sqrt{a^{* 2}+b^{* 2}} \\
& s=\frac{C^{*}}{L^{*}}
\end{aligned}
$$


Color differences, $\Delta E$, between samples, storage times and upper and lower surfaces of dietary cookies were calculated according to the equation [55]:

$$
\Delta E=\sqrt{\left(L_{2}^{*}-L_{1}^{*}\right)^{2}+\left(a_{2}^{*}-a_{1}^{*}\right)^{2}+\left(b_{2}^{*}-b_{1}^{*}\right)^{2}}
$$

\section{Statistical analysis}

For evaluation of color properties data of the dietary cookies, two-factorial analysis of variance ANOVA was applied. Duncan's range test was applied for evaluation of the significance of differences between the calculated mean values of measured parameters [56].

Overall differences of the samples of dietary cookies produced with different fiber sources were assessed by projecting the position of different samples in the factor plane using PCA multivariate test for set of sensory properties scores and for set of determined mean values of parameters characterizing sensory properties of examined dietary cookies samples [57].

Statistica 10.0 software was used for statistical data processing.

\section{RESULTS AND DISCUSSION}

\section{Sensory analysis}

The results of the conducted evaluation of sensory properties of dietary cookies (Table 3 ) point out the differences between different compositions of dietary cookies, but they also indicate the changes in evaluated sensory properties after 180 days of storage time.

Average sensory evaluation of all assessed sensory properties (Table 3 ) varied in a quite narrow range for all tested cookie compositions, regardless of applied dietary fiber sources. Fresh products were evaluated in average from 4.3 points (cookies with addition of inulin and oligofructose) to 4.6 points (cookies with addition of oat flakes; oat flakes and wholemeal wheat flour and wholemeal wheat flour and carob flour). The products stored for 180 days were evaluated in average from 4.0 points (cookies with addition of inulin and oligofructose) to 4.3 points (cookies with addition of oat flakes and wholemeal wheat flour and wholemeal wheat flour and carob flour).

However, individual evaluations of assessed sensory properties (Table 3 ) were differently ranked in dependence of fiber source, which was used in production. Cookies produced with addition of mixture wholemeal wheat flour and carob flour were assessed as the best regarding texture, aroma and taste properties, cookies with addition of mixture of oat flakes and wholemeal wheat flour regarding appearance, while the cookies with addition of inulin and oligofructose were assessed as the best regarding the mouth sensation. Ranking of the products regarding individual sensory properties was the same for fresh products and for products stored for 180 days. The lowest evaluation for three of five assessed sensory properties (appearance, texture and taste) was recorded in the case of addition of inulin and oligofructose as dietary fiber sources, while addition of mixture of wholemeal wheat flour and carob flour influenced in low evaluation of mouth sensation relating to chewiness and crispness.

The detected variations of sensory properties among the tested compositions of fiber enriched dietary cookies (Table 3 ) were also different in regard to assessed sensory property. The broadest variations for both fresh and products stored for 180 days, were detected regarding the appearance of the products: for

Table 3. Sensory properties of different compositions of dietary cookies after production and after 180 days of storage

\begin{tabular}{|c|c|c|c|c|c|c|}
\hline Fiber source & Appearance & Texture & Mouth sensation & Aroma & Taste & Average \\
\hline \multicolumn{7}{|c|}{ After production } \\
\hline Inulin + oligofructose & $3.6 \pm 0.20$ & $4.2 \pm 0.16$ & $4.8 \pm 0.17$ & $4.6 \pm 0.19$ & $4.1 \pm 0.08$ & 4.3 \\
\hline Oat flakes & $3.8 \pm 0.04$ & $4.6 \pm 0.05$ & $4.7 \pm 0.04$ & $4.9 \pm 0.05$ & $4.8 \pm 0.08$ & 4.6 \\
\hline Whole meal flour + oat flakes & $4.5 \pm 0.13$ & $4.3 \pm 0.14$ & $4.6 \pm 0.11$ & $4.7 \pm 0.08$ & $4.7 \pm 0.11$ & 4.6 \\
\hline Whole meal flour & $3.9 \pm 0.08$ & $4.4 \pm 0.11$ & $4.7 \pm 0.12$ & $4.7 \pm 0.04$ & $4.6 \pm 0.07$ & 4.5 \\
\hline Whole meal flour + carob & $4.0 \pm 0.16$ & $4.6 \pm 0.05$ & $4.2 \pm 0.07$ & $4.9 \pm 0.04$ & $4.9 \pm 0.04$ & 4.6 \\
\hline$X_{\text {mean }}$ & 3.97 & 4.43 & 4.63 & 4.78 & 4.65 & - \\
\hline $\mathrm{CV}^{*}, \%$ & 8.00 & 3.88 & 4.74 & 2.83 & 6.67 & - \\
\hline \multicolumn{7}{|c|}{ After 180 days } \\
\hline Inulin + oligofructose & $3.6 \pm 0.20$ & $3.3 \pm 0.19$ & $4.5 \pm 0.13$ & $4.5 \pm 0.09$ & $4.0 \pm 0.10$ & 4.0 \\
\hline Oat flakes & $3.7 \pm 0.08$ & $3.7 \pm 0.08$ & $4.2 \pm 0.07$ & $4.7 \pm 0.05$ & $4.6 \pm 0.09$ & 4.2 \\
\hline Whole meal flour + oat flakes & $4.2 \pm 0.11$ & $3.5 \pm 0.10$ & $4.4 \pm 0.11$ & $4.5 \pm 0.11$ & $4.5 \pm 0.10$ & 4.3 \\
\hline Whole meal flour & $3.9 \pm 0.05$ & $3.5 \pm 0.10$ & $4.4 \pm 0.11$ & $4.6 \pm 0.05$ & $4.4 \pm 0.06$ & 4.2 \\
\hline Whole meal flour + carob & $4.0 \pm 0.11$ & $3.8 \pm 0.04$ & $3.8 \pm 0.09$ & $4.9 \pm 0.05$ & $4.7 \pm 0.03$ & 4.2 \\
\hline$X_{\text {mean }}$ & 3.89 & 3.56 & 4.30 & 4.66 & 4.47 & - \\
\hline $\mathrm{CV}^{*}, \%$ & 6.58 & 5.48 & 6.37 & 3.16 & 6.26 & - \\
\hline
\end{tabular}


fresh products, appearance was evaluated in the range from 3.6 points (cookies with addition of inulin and oligofructose) to 4.5 points (cookies with addition of mixture of oat flakes and wholemeal wheat flour). The range of appearance evaluations, for the same compositions in the case of products stored for 180 days, was from 3.6 to 4.2 , respectively. The narrowest variation range was detected in the case of aroma, which was evaluated with over 4.5 points, i.e., as very pleasant aroma characteristic for cookies, for all tested cookie composition for fresh, as well as for products stored for 180 days.

Storing of cookies for 180 days (Table 3) had the most expressed influence on the texture of examined products. The average evaluation of texture properties dropped by 0.8 to 0.9 points after storage of 180 days regardless of source of dietary fiber used in the cookie composition. Storing for 180 days also had an effect on the mouth sensation of the products regarding chewiness and crispness. The average evaluation for mouth sensation dropped by 0.4 and 0.5 points in the case of utilization of oat flakes and mixture of wholemeal wheat flour and carob flour as dietary fiber sources, respectively. For all other sensory properties, the drop of evaluation after storage of 180 days was less than 0.3 points, with respect to fresh products.

Projection of samples of dietary cookies with different fiber sources in the factor plane on the basis of sensory properties after production and after 180 days (Figure 1) shows that the first two principal components explain almost $80 \%$ of variability (factor 1: $51.93 \%$, factor 2: $26.86 \%$ ) among sensory properties of dietary cookies produced with different fiber sources and their changes during storage of 180 days. It also indicates that the changes of sensory properties during storage, regardless of the cookie composition occur under the influence of the same factors resulting in approximately the same direction and size of shift of their positions in the factor plane.

\section{Color measurement}

Measurements of color properties for the tested compositions of dietary cookies with different fiber sources were conducted on upper and lower surface of fresh products and products stored for 180 days.

The comparison of color properties among different cookie compositions was performed for both upper and lower cookie surfaces, separately for fresh products and for products stored for 180 days (Table 4).

The lightness of the products for both upper and lower surface was significantly higher in the case of cookies with inulin and oligofructose as fiber sources, while it was significantly lower when wholemeal wheat flour and carob flour were used as fiber sources. Cookies produced with addition of oat flakes, wholemeal wheat flour and their mixtures as fiber sources appeared to show no difference concerning the lightness of upper surface, but the lower surface had significantly higher lightness in case of addition of oat flakes than in the case of utilization of wholemeal flour as the fiber source.

The $a^{*}$ values, with all measurements above zero, confirm that the red tone is dominating over the green in all fiber enriched dietary cookies. However, signifi-

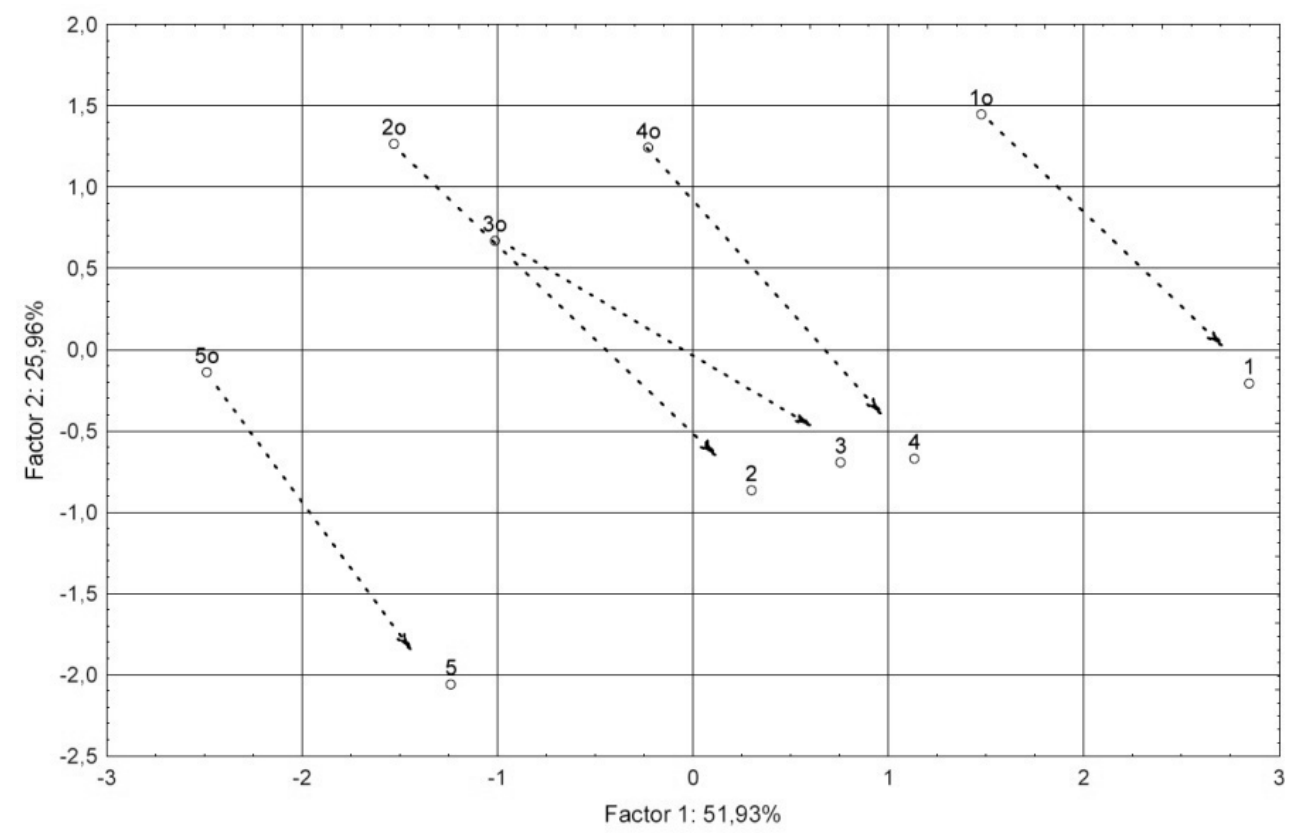

Figure 1. Projection of samples of dietary cookies in factor plane on the basis of sensory properties after production $\left(1_{0}, 2_{0}, 3_{0}, 4_{o}, 5_{0}\right)$ and after 180 days $(1,2,3,4,5)$ for cookies with different fiber sources $\left(1_{0}, 1\right.$ inulin and oligofructose; $2_{0}, 2$ oat flakes; $3_{0}, 3$ oat flakes and wholemeal flour; $4_{0}, 4$ wholemeal flour; $5_{0}, 5$ wholemeal flour and carob). 
Table 4. Instrumental determination of color of upper and lower surface of dietary cookies after production and after 180 days of storage

\begin{tabular}{|c|c|c|c|c|c|c|}
\hline Fiber source & $L^{*}$ & $a^{*}$ & $b^{*}$ & $C^{*}$ & $h^{\circ}$ & $s$ \\
\hline \multicolumn{7}{|c|}{ Upper surface } \\
\hline \multicolumn{7}{|c|}{ After production } \\
\hline Inulin + oligofructose & $61.33^{\mathrm{a}}$ & $10.69^{b c}$ & $35.43^{\mathrm{a}}$ & $37.27^{b}$ & $73.21^{b}$ & $0.61^{b}$ \\
\hline Oat flakes & $59.53^{b}$ & $7.69^{d}$ & $31.81^{b}$ & $32.73^{c}$ & $76.41^{\mathrm{a}}$ & $0.55^{d}$ \\
\hline Whole meal flour + oat flakes & $59.79^{\mathrm{ab}}$ & $9.84^{c}$ & $31.68^{b}$ & $33.18^{c}$ & $72.75^{b}$ & $0.55^{\mathrm{cd}}$ \\
\hline Whole meal flour & $59.26^{\mathrm{b}}$ & $14.42^{\mathrm{a}}$ & $36.00^{\mathrm{a}}$ & $38.78^{\mathrm{a}}$ & $68.18^{c}$ & $0.65^{a}$ \\
\hline Whole meal flour + carob & $49.04^{c}$ & $11.14^{b}$ & $26.38^{c}$ & $28.63^{d}$ & $67.11^{c}$ & $0.58^{\mathrm{bc}}$ \\
\hline \multicolumn{7}{|c|}{ After 180 days } \\
\hline Inulin + oligofructose & $62.05^{a}$ & $10.42^{c}$ & $34.95^{b}$ & $36.47^{b}$ & $73.40^{\mathrm{ab}}$ & $0.59^{\mathrm{bc}}$ \\
\hline Oat flakes & $58.35^{\mathrm{b}}$ & $8.51^{d}$ & $32.17^{c}$ & $33.28^{d}$ & $75.19^{\mathrm{a}}$ & $0.57^{c}$ \\
\hline Whole meal flour + oat flakes & $60.67^{\mathrm{ab}}$ & $9.89^{c}$ & $32.40^{c}$ & $33.88^{c}$ & $73.30^{b}$ & $0.56^{c}$ \\
\hline Whole meal flour & $60.15^{a b}$ & $14.24^{\mathrm{a}}$ & $36.34^{\mathrm{a}}$ & $39.03^{\mathrm{a}}$ & $68.61^{c}$ & $0.65^{a}$ \\
\hline Whole meal flour + carob & $47.48^{c}$ & $12.07^{b}$ & $26.20^{d}$ & $28.86^{e}$ & $65.28^{d}$ & $0.61^{b}$ \\
\hline \multicolumn{7}{|c|}{ Lower surface } \\
\hline \multicolumn{7}{|c|}{ After production } \\
\hline Inulin + oligofructose & $63.31^{a}$ & $10.74^{c}$ & $35.29^{\mathrm{a}}$ & $36.89^{\mathrm{a}}$ & $73.05^{\mathrm{a}}$ & $0.58^{b}$ \\
\hline Oat flakes & $58.58^{b}$ & $9.73^{d}$ & $34.53^{\mathrm{ab}}$ & $35.85^{b}$ & $74.25^{\mathrm{a}}$ & $0.61^{b}$ \\
\hline Whole meal flour + oat flakes & $56.30^{\mathrm{bc}}$ & $11.33^{c}$ & $32.46^{\mathrm{c}}$ & $34.38^{\mathrm{c}}$ & $70.61^{b}$ & $0.61^{b}$ \\
\hline Whole meal flour & $55.24^{c}$ & $14.57^{\mathrm{a}}$ & $33.50^{\mathrm{bc}}$ & $36.53^{\mathrm{ab}}$ & $66.50^{c}$ & $0.66^{\mathrm{a}}$ \\
\hline Whole meal flour + carob & $48.52^{d}$ & $12.16^{\mathrm{b}}$ & $27.32^{d}$ & $28.70^{d}$ & $66.01^{c}$ & $0.59^{b}$ \\
\hline \multicolumn{7}{|c|}{ After 180 days } \\
\hline Inulin + oligofructose & $64.15^{a}$ & $10.62^{c}$ & $35.78^{\mathrm{a}}$ & $37.33^{\mathrm{a}}$ & $73.47^{\mathrm{a}}$ & $0.58^{b}$ \\
\hline Oat flakes & $59.66^{\mathrm{b}}$ & $9.31^{d}$ & $34.13^{b}$ & $35.38^{\mathrm{bc}}$ & $74.74^{\mathrm{a}}$ & $0.59^{b}$ \\
\hline Whole meal flour + oat flakes & $57.15^{\mathrm{bc}}$ & $11.27^{b c}$ & $32.77^{c}$ & $34.66^{c}$ & $71.04^{b}$ & $0.61^{\mathrm{ab}}$ \\
\hline Whole meal flour & $56.08^{\mathrm{c}}$ & $14.61^{\mathrm{a}}$ & $33.72^{b c}$ & $36.75^{b}$ & $66.57^{c}$ & $0.66^{\mathrm{a}}$ \\
\hline Whole meal flour + carob & $47.87^{d}$ & $12.21^{b}$ & $26.71^{d}$ & $29.38^{d}$ & $65.46^{c}$ & $0.61^{\mathrm{ab}}$ \\
\hline
\end{tabular}

cantly more expressed red tone was detected for both surfaces of dietary cookies produced with the addition of wholemeal flour as fiber source, while dietary cookies produced with oat flakes had significantly less expressed red tone.

The $b^{*}$ values, with all measurements high above zero, confirm that the yellow tone is dominating over the blue in all fiber enriched dietary cookies, with the yellow tone being more expressed than the red tone. The intensity of the yellow tone for different dietary cookies compositions differed regarding the surface at which it was measured. The most expressed yellow tone of upper surface was detected in the case of addition of cookies with wholemeal wheat flour as fiber source, while the most expressed yellow tone of lower surface had the product with inulin and oligofructose as fiber sources. The same products had the highest value of chroma of upper and lower product surfaces respectively.

The lowest values for chroma were detected at the upper surfaces for the products containing oat flakes as fiber source, both alone and in the mixture with whole- meal wheat flour. The lowest chroma at the lower surface was detected for the products containing carob flour as the dietary fiber source.

Although statistically different due to measurement precision, the hues are in the same area of the hue wheel, the area of light orange colors. Significantly higher hue values for both surfaces of cookies produced with addition of oat flakes and with addition of inulin and oligofructose, indicate that these products tend to have more expressed yellow tone while significantly lower hue values for cookies produced with addition of wholemeal wheat flour and carob flour indicate that this product tends to have more expressed red tone.

Regarding the color saturation, the conducted measurements confirm that addition of wholemeal wheat flour results in the most saturated color of dietary cookies.

The color differences were calculated for both surfaces of fresh products and products stored for 180 days (Table 5). According to the statement of Young and Whittle [58], as well as of Kim et al. [59], color 
Table 5. Color differences, $\Delta E$, for lower and upper surface between different compositions of dietary cookies after production and after 180 days of storage

\begin{tabular}{|c|c|c|c|c|}
\hline Fibre sorce & Inulin + oligofructose & Oat flakes & Whole meal flour + oat flakes & Whole meal flour \\
\hline \multicolumn{5}{|c|}{ Upper surface } \\
\hline \multicolumn{5}{|c|}{ After production } \\
\hline Oat flakes & $5.04^{(3)}$ & & & \\
\hline Whole meal flour + oat flakes & $4.14^{(3)}$ & $2.17^{(2)}$ & & \\
\hline Whole meal flour & $4.30^{(3)}$ & $7.93^{(4)}$ & $6.31^{(4)}$ & \\
\hline Whole meal flour + carob & $15.27^{(5)}$ & $12 ., 30^{(5)}$ & $12.06^{(5)}$ & $14.42^{(5)}$ \\
\hline \multicolumn{5}{|l|}{ After 180 days } \\
\hline Oat flakes & $5.00^{(3)}$ & & & \\
\hline Whole meal flour + oat flakes & $2.94^{(2)}$ & $2.70^{(2)}$ & & \\
\hline Whole meal flour & $4.49^{(3)}$ & $7.31^{(4)}$ & $5.89^{(3)}$ & \\
\hline Whole meal flour + carob & $17.07^{(5)}$ & $12.91^{(5)}$ & $14.74^{(5)}$ & $16.38^{(5)}$ \\
\hline \multicolumn{5}{|c|}{ Lower surface } \\
\hline \multicolumn{5}{|l|}{ After production } \\
\hline Oat flakes & $4.89^{(3)}$ & & & \\
\hline Whole meal flour + oat flakes & $7.57^{(4)}$ & $3.47^{(3)}$ & & \\
\hline Whole meal flour & $9.11^{(4)}$ & $5.97^{(3)}$ & $3.56^{(3)}$ & \\
\hline Whole meal flour + carob & $16.86^{(5)}$ & $12.62^{(5)}$ & $9.37^{(4)}$ & $9.45^{(4)}$ \\
\hline \multicolumn{5}{|l|}{ After 180 days } \\
\hline Oat flakes & $4.96^{(3)}$ & & & \\
\hline Whole meal flour + oat flakes & $7.65^{(4)}$ & $3.46^{(3)}$ & & \\
\hline Whole meal flour & $9.24^{(4)}$ & $6.41^{(4)}$ & $3.64^{(3)}$ & \\
\hline Whole meal flour + carob & $18.70^{(5)}$ & $14.22^{(5)}$ & $11.12^{(5)}$ & $11.06^{(5)}$ \\
\hline
\end{tabular}

differences were categorized as imperceptible differences (0-0.5), slight differences (0.5-1.5), just noticeable differences (1.5-3.0), marked differences (3.0-6.0), extremely marked differences (6.0-12.0) and colors of different shades (above 12.0).

In comparison to other products, dietary cookies produced with addition of carob and wholemeal wheat flour had completely different color of different shade. This difference was larger for stored products than for fresh products with least expressed difference at lower surface of fresh cookies.

Just noticeable difference of colors was detected between cookies with oat flakes and mixture of oat flakes and wholemeal flour while all other color differences were at the level of marked and/or extremely marked differences.

Comparison of color properties of fresh products and products stored for 180 days was performed individually for every tested composition of fiber enriched cookies for upper and for lower surface of the products.

Statistically significant difference between color properties of fresh products and products stored for 180 days was detected only in the case of values for $a^{*}$ and for hue of the upper surface of cookies produced with addition of oat flakes as the fiber source, indicating expression of more intense red tone with long lasting storage of this product (Table 6).

Statistically significant differences between upper and lower surfaces of the same product were detected in the cases of: a) higher lightness of upper surface of products obtained with wholemeal wheat flour and mixture of wholemeal wheat flour and oat flakes for both fresh and stored products; b) more expressed red and yellow tone, as well as higher chroma and hue of lower surface for products containing oat flakes and their mixture with wholemeal flour; c) more saturated color of lower surface in the case of addition of mixture of oat flakes and wholemeal flour and of inulin and oligofructose as fiber sources.

In the case of wholemeal flour with and without carob, as samples with highest color saturation, there were neither differences between surfaces, nor during storage.

Comparison of color differences between upper and lower surfaces of dietary cookies produced with different fiber sources is presented in Table 7. The detected color differences between upper and lower surface of the products can be categorized as marked differences in the case of cookies produced with addition of whole- 
Table 6. Differences in color parameters for upper and lower surfaces and after 180 days of storage for different compositions of dietary cookies

\begin{tabular}{|c|c|c|c|c|c|c|c|}
\hline \multicolumn{2}{|c|}{ Fiber source } & $L^{*}$ & $a^{*}$ & $b^{*}$ & $C^{*}$ & $h^{\circ}$ & $s$ \\
\hline \multicolumn{8}{|c|}{ Inulin + oligofructose } \\
\hline \multirow[t]{2}{*}{ Upper } & After production & $61.33^{\mathrm{a}}$ & $10.69^{a}$ & $35.43^{\mathrm{a}}$ & $37.27^{\mathrm{a}}$ & $73.21^{\mathrm{a}}$ & $0.61^{a}$ \\
\hline & After 180 days & $62.05^{\mathrm{a}}$ & $10.42^{\mathrm{a}}$ & $34.95^{\mathrm{a}}$ & $36.47^{a}$ & $73.40^{\mathrm{a}}$ & $0.59^{\mathrm{ab}}$ \\
\hline \multirow[t]{2}{*}{ Lower } & After production & $63.31^{a}$ & $10.74^{\mathrm{a}}$ & $35.29^{\mathrm{a}}$ & $36.89^{a}$ & $73.05^{\mathrm{a}}$ & $0.58^{b}$ \\
\hline & After 180 days & $64.15^{\mathrm{a}}$ & $10.62^{a}$ & $35.78^{\mathrm{a}}$ & $37.33^{a}$ & $73.47^{\mathrm{a}}$ & $0.58^{b}$ \\
\hline \multicolumn{8}{|c|}{ Oat flakes } \\
\hline \multirow[t]{2}{*}{ Upper } & After production & $59.53^{\mathrm{a}}$ & $7.69^{c}$ & $31.81^{b}$ & $32.73^{b}$ & $76.41^{a}$ & $0.55^{c}$ \\
\hline & After 180 days & $58.35^{\mathrm{a}}$ & $8.51^{b}$ & $32.17^{b}$ & $33.28^{b}$ & $75.19^{b}$ & $0.57^{b c}$ \\
\hline \multirow[t]{2}{*}{ Lower } & After production & $58.58^{a}$ & $9.73^{a}$ & $34.53^{\mathrm{a}}$ & $35.85^{\mathrm{a}}$ & $74.25^{b}$ & $0.61^{a}$ \\
\hline & After 180 days & $59.66^{\mathrm{a}}$ & $9.31^{\mathrm{a}}$ & $34.13^{\mathrm{a}}$ & $35.38^{\mathrm{a}}$ & $74.74^{b}$ & $0.59^{\mathrm{ab}}$ \\
\hline \multicolumn{8}{|c|}{ Oat flakes + whole meal flour } \\
\hline \multirow[t]{2}{*}{ Upper } & After production & $59.79^{\mathrm{a}}$ & $9.84^{b}$ & $31.68^{b}$ & $33.18^{b}$ & $72.75^{\mathrm{ab}}$ & $0.55^{b}$ \\
\hline & After 180 days & $60.67^{\mathrm{a}}$ & $9.89^{b}$ & $32.40^{\mathrm{ab}}$ & $33.88^{\mathrm{ab}}$ & $73.30^{\mathrm{a}}$ & $0.56^{b}$ \\
\hline \multirow[t]{2}{*}{ Lower } & After production & $56.30^{\mathrm{b}}$ & $11.33^{\mathrm{a}}$ & $32.46^{\mathrm{ab}}$ & $34.38^{\mathrm{a}}$ & $70.61^{c}$ & $0.61^{a}$ \\
\hline & After 180 days & $57.15^{b}$ & $11.27^{\mathrm{a}}$ & $32.77^{\mathrm{a}}$ & $34.66^{\mathrm{a}}$ & $71.04^{b c}$ & $0.61^{a}$ \\
\hline \multicolumn{8}{|c|}{ Whole meal flour } \\
\hline \multirow[t]{2}{*}{ Upper } & After production & $59.26^{\mathrm{a}}$ & $14.42^{\mathrm{a}}$ & $36.00^{\mathrm{a}}$ & $38.78^{\mathrm{a}}$ & $68.18^{\mathrm{a}}$ & $0.65^{a}$ \\
\hline & After 180 days & $60.15^{\mathrm{a}}$ & $14.24^{\mathrm{a}}$ & $36.34^{\mathrm{a}}$ & $39.03^{\mathrm{a}}$ & $68.61^{\mathrm{a}}$ & $0.65^{a}$ \\
\hline \multirow[t]{2}{*}{ Lower } & After production & $55.24^{\mathrm{b}}$ & $14.57^{\mathrm{a}}$ & $33.50^{b}$ & $36.53^{b}$ & $66.50^{b}$ & $0.66^{a}$ \\
\hline & After 180 days & $56.08^{b}$ & $14.61^{\mathrm{a}}$ & $33.72^{b}$ & $36.75^{b}$ & $66.57^{b}$ & $0.66^{\mathrm{a}}$ \\
\hline \multicolumn{8}{|c|}{ Whole meal flour + carob } \\
\hline \multirow[t]{2}{*}{ Upper } & After production & $49.04^{a}$ & $11.14^{\mathrm{a}}$ & $26.38^{\mathrm{a}}$ & $28.63^{\mathrm{a}}$ & $67.11^{\mathrm{a}}$ & $0.58^{\mathrm{a}}$ \\
\hline & After 180 days & $47.48^{a}$ & $12.07^{\mathrm{a}}$ & $26.20^{\mathrm{a}}$ & $28.86^{\mathrm{a}}$ & $65.28^{\mathrm{a}}$ & $0.61^{a}$ \\
\hline \multirow[t]{2}{*}{ Lower } & After production & $48.52^{\mathrm{a}}$ & $12.16^{\mathrm{a}}$ & $27.32^{\mathrm{a}}$ & $28.70^{\mathrm{a}}$ & $66.01^{a}$ & $0.59^{\mathrm{a}}$ \\
\hline & After 180 days & $47.87^{\mathrm{a}}$ & $12.21^{\mathrm{a}}$ & $26.71^{\mathrm{a}}$ & $29.38^{\mathrm{a}}$ & $65.46^{\mathrm{a}}$ & $0.61^{a}$ \\
\hline
\end{tabular}

meal wheat flour and its mixture with oat flakes. Differences between surfaces were categorized as slight or as just noticeable in the case of other applied cookie compositions.

Color differences between fresh products and products stored for 180 days were categorized as just noticeable for both surfaces and for all examined dietary cookies compositions.

Projection of samples of dietary cookies with different fiber sources in factor plane based on color properties, with the first two principal components explaining over $97 \%$ of variability, points out at clear grouping of examined cookie samples based on their composition including different sources of dietary fiber. Positions of samples with wholemeal flour (composition 4) and with its mixture with carob flour (composition 5) indicate that these two constituents are the ones with the most expressed influence on color properties.

\section{CONCLUSIONS}

Utilization of examined sources of dietary fiber in production of fiber enriched dietary cookies (inulin and oligofructose, oat flakes, mixture of oat flakes and wholemeal flour, wholemeal wheat flour and mixture of wholemeal wheat flour and carob flour) enables production of cookies with highly evaluated sensory properties concerning the appearance, texture, mouth sensation, aroma and taste of the products. The most expressed influence on obtaining of lower evaluated sensory properties has addition of inulin and oligofructose as dietary fiber sources.

Sensory properties of dietary cookies produced with different dietary fiber sources express the widest difference range regarding the appearance of the products.

The main effect in which results the storage of dietary cookies for 180 days, regardless of utilized source of dietary fiber, is the deterioration of product texture expressed as increased crumbling of the products and appearance of surface breakages. The changes of sensory properties during storage, regardless of the cookie composition, occur under the influence of the same factors related most probably to water loss of products during storage.

Dietary cookies, regardless of the utilized dietary fiber source, have the color in the area of light orange colors. Cookies produced with addition of oat flakes and 
Table 7. Color differences, $\Delta E$, for upper and lower surfaces and after 180 days of storage for different compositions of dietary cookies

\begin{tabular}{|c|c|c|c|c|c|}
\hline \multicolumn{2}{|c|}{ Prebiotics } & \multicolumn{2}{|c|}{ Upper surface } & \multicolumn{2}{|c|}{ Lower surface } \\
\hline Predio & & \multirow{2}{*}{$\begin{array}{c}\text { After production } \\
0.00\end{array}$} & \multirow[t]{2}{*}{ After 180 days } & \multirow[t]{2}{*}{ After production } & \multirow[t]{2}{*}{ After 180 days } \\
\hline Upper & After production & & & & \\
\hline & After 180 days & $0.91^{(1)}$ & 0.00 & & \\
\hline \multirow[t]{2}{*}{ Lower } & After production & $1.98^{(2)}$ & $1.34^{(1)}$ & 0.00 & \\
\hline & After 180 days & $2.84^{(2)}$ & $2.27^{(2)}$ & $0.99^{(1)}$ & 0.00 \\
\hline \multicolumn{6}{|c|}{ Oat flakes } \\
\hline \multirow[t]{2}{*}{ Upper } & After production & 0.00 & & & \\
\hline & After 180 days & $1.48^{(1)}$ & 0.00 & & \\
\hline \multirow[t]{2}{*}{ Lower } & After production & $3.53^{(3)}$ & $2.67^{(2)}$ & 0.00 & \\
\hline & After 180 days & $2.83^{(2)}$ & $2.48^{(2)}$ & $1.22^{(1)}$ & 0.00 \\
\hline \multicolumn{6}{|c|}{ Whole meal flour + oat flakes } \\
\hline \multirow[t]{2}{*}{ Upper } & After production & 0.00 & & & \\
\hline & After 180 days & $1.14^{(1)}$ & 0.00 & & \\
\hline \multirow[t]{2}{*}{ Lower } & After production & $3.87^{(3)}$ & $4.60^{(3)}$ & 0.00 & \\
\hline & After 180 days & $3.19^{(3)}$ & $3.80^{(3)}$ & $0.90^{(1)}$ & 0.00 \\
\hline \multicolumn{6}{|c|}{ Whole meal flour } \\
\hline \multirow[t]{2}{*}{ Upper } & After production & 0.00 & & & \\
\hline & After 180 days & $0.97^{(1)}$ & 0.00 & & \\
\hline \multirow[t]{2}{*}{ Lower } & After production & $4.74^{(3)}$ & $5.68^{(3)}$ & 0.00 & \\
\hline & After 180 days & $3.92^{(3)}$ & $4.85^{(3)}$ & $0.87^{(1)}$ & 0.00 \\
\hline \multicolumn{6}{|c|}{ Whole meal flour + carob } \\
\hline \multirow[t]{2}{*}{ Upper } & After production & 0.00 & & & \\
\hline & After 180 days & $1.83^{(2)}$ & 0.00 & & \\
\hline \multirow[t]{2}{*}{ Lower } & After production & $1.48^{(1)}$ & $1.53^{(2)}$ & 0.00 & \\
\hline & After 180 days & $1.62^{(2)}$ & $0.66^{(1)}$ & $0.89^{(1)}$ & 0.00 \\
\hline
\end{tabular}

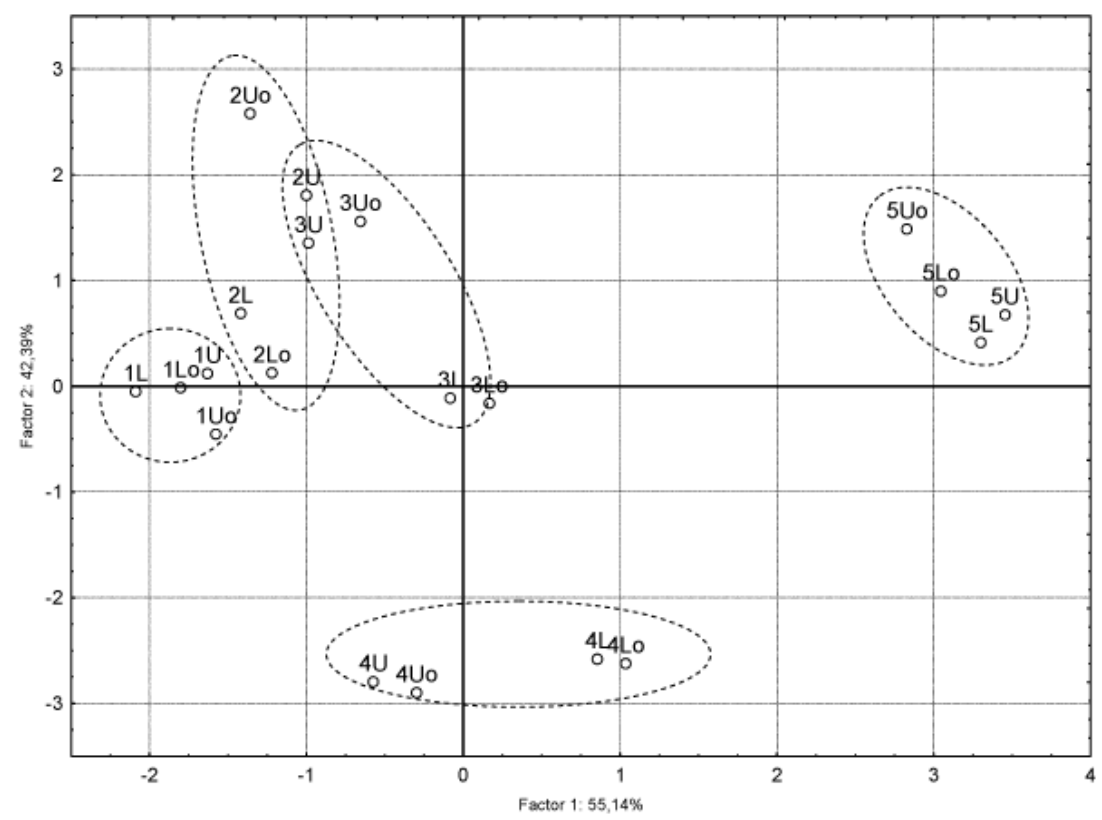

Figure 2. Projection of samples of dietary cookies with different fiber sources in factor plane on the basis of color properties (1 inulin and oligofructose; 2 oat flakes; 3 oat flakes and wholemeal flour; 4 wholemeal flour; 5 wholemeal flour and carob; U-uppper surface, $L$ - lower surface; subscript ${ }_{o}$ fresh products, without subscript mark products after storage of 180 days). 
with addition of inulin and oligofructose tend to have more expressed yellow tone, while cookies produced with addition of wholemeal wheat flour and carob flour tend to have more expressed red tone. Products in which wholemeal wheat flour is added have the most saturated color.

In comparison to other products, dietary cookies produced with addition of carob and wholemeal wheat flour had completely different color of different shade, while the color among products with other fiber sources was of the same shade but with marked and/or extremely marked difference except between products containing oat flakes with just noticeable difference.

Storage of 180 days does not influence significantly the color properties of dietary cookies. Color differences between upper and lower surface of dietary cookies are marked only in the case of addition of wholemeal flour and its mixture with oat flakes.

Wholemeal flour and carob flour are the constituents with the most expressed influence on color properties of dietary cookies.

\section{Acknowledgement}

This study was funded by the Ministry of Education, Science and Technological Development of the Republic of Serbia (Improvement and development of hygienic and technological procedures in the production of foodstuffs of animal origin in order to obtain high-quality and safe products competitive in world markets. Project No. 46009). The authors are sincerely grateful to the Ministry for financing and understanding.

\section{REFERENCES}

[1] J. Popov-Raljić, Lj. Stojšin, The Technology of the Confectionery Products, University of Belgrade, Faculty of Agriculture, Belgrade, 2007, pp. 217-225 (in Serbian).

[2] S.A. Turner, A. Luszczynska, L. Warner, R. Schwarzer, Emotional and uncontrolled eating styles and chocolate chip cookie consumption, A controlled trial of the effects of positive mood enhancement, Appetite $\mathbf{5 4}$ (2010) 143-149.

[3] J. Popov-Raljić, Technology of Ready-made Food. University of Novi Sad, Faculty of Technology, Novi Sad, 1999, pp. 1-185 (in Serbian).

[4] M.K. Sharif, M.S. Butt, F.M. Anjum, M. Nasir, R. Minhas, M.N. Qayyum, Extension of cookies shelf life by using rice bran oil, Int. J. Agric. Biol. 5 (2003) 455-457.

[5] A. Rukshan, Consideration of issue of special flour production for confectionery products made with flour, Wheat-Bread 3 (2001) 53-58.

[6] B. Pajin, O. Jovanović, A. Torbica, M. Šarić, Technological quality of domestic varieties of wheat for confectionery products made from flour, Wheat-Bread 32 (2005) 199$-203$.

[7] B. Pareyt, J. A. Delcour, The role of wheat flour constituents, sugars and fat in low moisture cereal based products: A review on sugar -snap cookies, Crit. Rev. Food Sci. Nutr. 48 (2008) 824-839.

[8] B. Pareyt, F. Talhaoui, G. Kerckhofs, K. Brijs, H. Goesaert, M. Wevers, J.A. Delcour, The role of sugar and fat in sugar-snap cookies: Structural and textural properties, J. Food. Eng. 90 (2009) 400-408.

[9] V.B. Duffy, G.H. Anderson, Position of the American Dietetic Association: Use of nutritive and non-nutritive sweeteners, J. Am. Diet. Assoc. 98 (1998) 580-587.

[10] A. Drewnowski, K. Nordensten, J. Dwyer, Replacing sugar and fat in cookies: Impact on product quality and preference, Food. Qual. Prefer. 9 (1998) 13-20.

[11] F. Tufail, I. Pasha, M.S. Butt, N. Abbas, S. Afzaal, Use of date syrup in the preparation of low caloric cakes replacing sucrose, Pak. J. Agric. Sci. 3 (2002) 149-153.

[12] I. Pasha, M.S. Butt, F.M. Anjum, N. Shehzadi, Effect of dietetic sweeteners on the quality of cookies, Int. J. Agric. Biol. 4 (2002) 245-248.

[13] T.P. Taylor, O. Fasina, L.N. Bell, Physical properties and the tendency of consumers from cookies prepared replacing sucrose with tagatose, J. Food. Sci. 73 (2008) 145-151.

[14] B. Pareyt, M. Goovaerts, W.F. Broekaert, J.A. Delcour, Arabinoxylan oligosaccharides (AXOS) as a potential sucrose replacer in sugar-snap cookies, Lwt-Food. Sci. Technol. 44 (2001) 725-728.

[15] M. Singh, A. Mohamed, Influence of gluten-soy protein blends on the quality of reduced carbohydrates cookies, Lwt-Food. Sci. Technol. 40 (2007) 353-360.

[16] M. Gavrilović, O. Jovanović, Fats in coffectionary industry, Hrana i ishrana 21 (1980) 275-282 (in Serbian).

[17] O. Charlton, M.K. Sawyer-Morse, Effect of fat replacement on sensory attributes of chocolate chip cookies, J. Am. Diet. Assoc. 96 (1996) 1288-1290.

[18] M. Adair, S. Knight, G. Gates, acceptability of peanut butter cookies prepared using mungbean paste as a fat ingredient substitute, J. Am. Diet. Assoc. 101 (2011) 467-469.

[19] E.I. Zoulias, V. Oreopoulou, C. Tzia, Textural properties of low-fat cookies containing carbohydrate- or proteinbased fat replacers. J. Food. Eng. 55 (2002) 337-342.

[20] A. Waheed, G. Rasool, A. Asghar, Effect of interesterified palm and cottonseed oil blends on cookie quality. Agric. Biol. J. North Am. 1 (2010) 402-406.

[21] A. Goldstein, K. Seetharaman, Effect of a novel monoglycerides stabilized oil in water emulsion shortening on cookie properties. Food Res. Int. 44 (2011) 1476-1481.

[22] M.U. Arshad, F.M. Anjum, T. Zahoor, Nutritional assessment of cookies supplemented with defatted wheat germ. Food Chem. 102 (2007) 123-128.

[23] M. Nasir, M.S. Butt, F.M. Anjum, A. Jamil, J. Ahmad, Physical and sensory properties of maize germ oil fortified cakes. Int. J. Agric. Biol. 11 (2009) 311-315.

[24] B. Škrbić, J. Cvejanov, The enrichment of wheat cookies with high-oleic sunflower seed and hull-less barley flour: Impact on nutritional composition, content of heavy elements and physical properties. Food Chem. 124 (2011) 1416-1422. 
[25] B.V. McCleary, L. Prosky, Advanced Dietary Fiber Technology. Bleckwell Sciences, Oxford, U.K, 2001

[26] N.G. Asp, Definition and analysis of dietary fiber in the context of food carbohydrates, In: J.W. Van der Kamp, N. G. Asp, J. Miller Jones, G. Schaafsma (Eds.), Dietary Fiber: Bio-Active Carbohydrates for Food and Feed, Wageningen Academic Publishers, 2004, pp. 21-26.

[27] H.K. Sreenath, K.R. Sudarshanakrishna, N.N. Prasad, K.S. Mysore, Characteristics of some fiber incorporated cake preparations and their dietary fiber content. Starch/ /Stärke, 48 (1996) 72-76.

[28] B. Šebašić, I. Vedrina-Dragojević, D. Vitali, M. Hečimović, I. Dragičević, Raw materials in fiber enriched biscuits production as source of total phenols, Agriculturae Conspectus Scientificus 72 (2007) 265-270.

[29] R.M. Saunders, The properties of rice bran as a food stuff, Cereal Food World 35 (1990) 632-639.

[30] H.A. Abdul, S.L. Yu, Functional properties of dietary fiber prepared from defatted rice bran. Food Chem. 68 (2000) 15-19.

[31] A. Aparicio-Saguilán, S.G. Sáyago-Ayerdi, A. Vargas-Torres, J. Tovar, T.E. Ascencio-Otero, L.A. Bello-Pérez, Slowly digestible cookies prepared from resistant starch-rich lintnerized banana starch, J, Food Compos Anal. 20 (2007) 175-181.

[32] G.R. Gibson, E.R. Beatty, X. Wang, J.H. Cummings, Selective stimulation of bifidobacteria in the human colon by oligofructose and inulin, Gastroenterology 108 (1995) 975-982.

[33] F. Zucco, Y. Borsuk, S.D. Arntfield, Physical and nutritional evaluation of wheat cookies supplemented with pulse flours of different particle sizes, Lwt-Food. Sci. Technol. 10 (2011) 2070-2076.

[34] M.F. Piteira, J.M. Maia, A. Raymundo, I. Sousa, Extensional flow behavior of natural fiber-filled dough and its relationship with structure and properties. J. NonNewton Fluid. 137 (2006) 72-80.

[35] M. Horvatic, M. Eres, Protein nutritive quality during production and storage of dietetic biscuits. J. Sci. Food Agr. 82 (2002) 1617-1620.

[36] N. Bilgiçli, Ş. Ibanoglu, E. N. Herken, Effect of dietary fiber addition on the selected nutritional properties of cookies. J. Food Eng. 78 (2007) 86-89.

[37] E.S. Brennan, E. Samyue, Evolution of starch degradation and textural characteristics of dietary fiber enriched biscuits, Int. J. Food Prop. 7 (2004) 647-657.

[38] D.M. Peterson, Oat antioxidants. J. Cereal. Sci. 33 (2001) 115-129.

[39] S. Kumazawa, M. Taniguchi, Y. Suzuki, M. Shimura, M.S. Kwon, T. Nakayama, Antioxidant Activity of Polyphenols in Carob Pods, J Agric. Food Chem. 82 (2002) 373-377.

[40] Y. Malkki, E. Virtanen, Gastrointestinal effects of oat bran and oat gum - A review, Lwt-Food. Sci. Technol. 34 (2001) 337-347.
[41] C.L. Emmons, D. M. Peterson, Antioxidant activity and phenolic contents of groats and hulls. Cereal Chem. 76 (1999) 902-906.

[42] G. Panfli, A. Fratianni, M. Irano, Normal phase high performance liquid chromatography method for the determination of tocopherols and tocotrienols in cereals, J. Agric. Food Chem. 51 (2003) 3940-3944.

[43] ISO 8589. Sensory Analysis - General guidance for the design of test rooms, 1988

[44] ISO 8586-1. Sensory Analysis - General guidance for selection, training and monitoring of assessors-Part 1 : Selected assessors, 1993.

[45] ISO 8586-2. Sensory Analysis-General guidance for selection, training and monitoring of assessors-Part 2: Experts, 1994.

[46] ISO 5492. Sensory Analysis-Vocabulary, 1992.

[47] ISO 11036. Sensory Analysis-Methodology-Texture profile, 1994.

[48] [ISO 5496. Sensory Analysis - Methodology - Initiation and training of assessors in the detection and recognition of odors, 1992.

[49] ISO 11037. Sensory Analysis-General guidance and test method for assessment of the color of food, 1999.

[50] ISO 3972. Sensory Analysis-Methodology-Method of investigating sensitivity of taste, 1991.

[51] J. Popov-Raljić, J. Laličić, R. Gorjanović, Proposed options of valuation of confectionery products made with flour such as cookies, crackers and salty pastry. WheatBread 4-5 (2005) 179-185 (in Serbian).

[52] J. Hutchings, Food color and appearance, $2^{\text {nd }}$ ed., Aspen Publishers, Inc., Gaithersburg, MD, 1999.

[53] J. Hutchings, R. Luo, W. Ji, Calibrated color imaging analysis of food, in: Color in Food, B.D. MacDougall, Woodhead Publishing in Food Science and Technology, Cambridge, England, Chapter 14, 2002, pp. 352-366.

[54] CIE Colorimetry ( $2^{\text {nd }}$ ed.), Publication CIE No. 15.2, Vienna: Central Bureau of the Commission Internationale de L'Ectarge. 1986.

[55] CIE Colorimetry Committee, Technical notes: working program on color differences. J. Opt. Soc. Am. 64 (1986) 896-897.

[56] S. Hadživuković, Statistical Methods, Faculty of Agriculture, Belgrade, 1991 (in Serbian).

[57] M. Lovrić, Method of the Nonparametric Statistical Conclusion, University of Belgrade, Faculty of Economics, Belgrade, 2002 (in Serbian).

[58] K.W. Young, K.J. Whittle, Color measurement of fish minces using Hunter $L, a, b$ values, J. Sci. Food Agr. 36 (1985) 383-392.

[59] S. Kim, J. Park, I. K. Hwang, Quality attributes of various varieties of Korean red pepper powders (Capsicum annuum L.) and color stability during sunlight exposure. J. Food Sci. 67 (2002) 2957-2961. 


\section{IZVOD}

\section{SENZORNA SVOJSTVA I BOJA DIJETNOG KEKSA SA RAZLIČITIM IZVORIMA DIJETNIH VLAKANA TOKOM 180 DANA SKLADIŠTENJA}

Jovanka V. Popov-Raljić ${ }^{1}$, Jasna S. Mastilović ${ }^{2}$, Jovanka G. Laličić-Petronijević ${ }^{1}$, Žarko S. Kevrešan $^{2}$, Mirjana A. Demin ${ }^{1}$

${ }^{1}$ Univerzitet u Beogradu, Poljoprivredni fakultet, Beograd, Srbija

${ }^{2}$ Univerzitet u Novom Sadu, Naučni institut za prehrambene tehnologije, Novi Sad, Srbija

(Naučni rad)

Cilj istraživanja je ispitivanje senzornih karakteristika dijetetskog keksa proizvedenog sa dodacima dijetetskih vlakana iz različitih izvora (inulin i oligofruktoza, ražene pahuljice, mešavina raženih pahuljica i integralnog brašna, integralno brašno i mešavina integralnog brašna i brašna rogača) i instrumentalno merenje promena boje gornje i donje površine keksa, korišćenjem "Minolta“ Chroma meter CR 400 tristimulus colorimeter tokom skladištenja na temperaturi od 18-20 ${ }^{\circ} \mathrm{C}$ do 180 dana. Za dodatak inulina i oligofruktoze je utvrđeno da je izvor dijetetskih vlakana koji je najviše uticao na senzorna svojstva. Skladištenje od 180 dana imalo je najveći uticaj na teksturne promene dejetetskog keksa, nezavisno od izvora dijetetskih vlakana. Razlike $u$ boji izračunate na bazi instrumentalno merenih svojstva boje proizvoda $\left(L^{*}, a^{*}, b^{*}\right)$ između proizvoda različitog sastava u pogledu izvora dijetnih vlakana su bile izražene do ekstremno izražene, sa najupečatljivijim razlikama registrovanim u slučaju dodatka brašna od rogača.

Ključne reči: Dijetetski keks • Senzorne karakteristike • Merenje boje • Sastav • Čuvanje 